\title{
Anomalies and asymmetry of wing venation pattern in Carniolan and Egyptian bee populations in Egypt
}

\author{
Adel M. M. Mazeed \\ Faculty of Agriculture, Department of Entomology, Cairo University, Egypt, \\ E-mail: adelmazeed@hotmail.com
}

\section{ABSTRACT}

The presence of unusual wing venation and asymmetry of the forewing in Carniolan and Egyptian honeybees in Egypt were recorded. The present study indicates that, Carniolan bees had higher rate of unusual veins than the Egyptian bees. The frequency of adventitious veins was much higher than incomplete veins, and the marginal cell had the highest frequency of adventitious veins, and the first cubital cell had the lowest. The adventitious vein of the marginal cell characterized the Egyptian bees, whereas the adventitious vein of the third cubital cell characterized the Carniolan bees population. In the hind wing, the incomplete veins were absent, and only an extension of the medial vein appeared with higher frequency in Egyptian bees than in Carniolan bees. The left and right forewings of Egyptian bees are more homogenous than those of Carniolan bees. All wing coordinates exhibited significant fluctuating asymmetry in Carniolan bees, in comparison to 15 of 31 coordinates in Egyptian bees. With respect to directional asymmetry, 19 and 27 of 31 coordinates showed significant directional asymmetry in Carniolan bees from Manzala and New Valley respectively, but only 13 in Egyptian bees.

Keywords: Egyptian bees, Carniolan bees, wing venation, wing cells, anomalies, asymmetry.

\section{INTRODUCTION}

Morphological characters are useful tool for discriminating different honeybee populations, among them are characters related to wing characteristics. (Alpatov, 1929, Goetze, 1964, Ruttner, 1988; Mattu and Verma, 1984).

Biometrical measurements of wings are important in classifying different races and strains of honeybee (Ruttner et al, 1978; Mattu and Verma, 1984, Klebs,1995) and has been developed further for the discrimination of populations within bees subspecies (Kauhausen \&and Keller, 1994), or as alabel for the evaluation of either other biological characters (Woyke, 1987).

Great attention has been paid from many researchers to the changes taking place in wing venation pattern (Goetze, 1936; Ruttner, 1952; Soose, 1954; Goetze, 1959; Baehrman, 1963; Tan et al 2008). Anomalies of wing venation pattern is one of these changes which occur either as surplus or incomplete veins in the workers, queens or drones (Baehrman, 1963 and Akahira \& Sakagami, 1959). Whereas, Goetze (1959) indicated that these characters are not heritable and caused by unsuitable environmental factors during the development of the individual bees. Baehrman (1963) indicated that these characters can be caused by genetic factors.

In addition, Fluctuating asymmetry (FA) i.e., random deviations from perfect bilateral symmetry between sides of a bilaterally systematical organisms, is another type of these changes in the wing which have been employed as an indicator of the level of developmental stability of an organism (Mather, 1953; Beardmore, 1960; Reeve, 
1960; Gupta, 1978; Parsons, 1992; Palmer \& Strobeck, 1986; Klingenberg, \& McIntyre, 1998; Vishalakshi \& Singh, 2009).

Various wing characters have been successfully used to assess FA in bees in previous studies (Brueckner 1978 a\&b; Clarke et al. 1992; Clarke \& Oldroyd 1996; Smith et al. 1997). Earlier studies showed effect of both environmental stress. (Valentine \&Soule, 1973; Valkama \& Kozlov, 2001) and genetic stress on the level of asymmetry (Cale \& Gowen, 1956; Brueckner, 1978 a\&b, 1979; Graham \& Felley, 1985; Ross and Robertson, 1990)

In this study, the frequency of abnormal veins and the symmetry in fore wing venation were studied in workers of Carniolan and Egyptian honeybee populations in Egypt.

\section{MATERIAL AND METHODS}

For this purpose, 30 colonies were chosen randomly from Egyptian and Carniolan bees for sampling worker honeybees. Searching on unusual wing venation pattern, 5 forewing and one hind wing cells were chosen to investigate the presence of adventitious or incomplete wing veins. In addition, 31 coordinates on the forewing were used to evaluate the symmetry of right and left forewing. The research material was as follows:

Apis mellifera lamarckii, from sewa oasis

A.m carnica, from Dakahlia Governorate (Manzala),

A. m.carnica, from Valley governorate (El-Dakhla).

From each colony, about 10-15 worker were collected and preserving in Alkohol 70\% until their dissecting.

From each worker bees, pairs of forewing were dissected (in ethanol) and airdried to the glass slides while ethanol evaporated, and dry mounts were digitally photographed,

\section{Asymmetry of wing venation:}

The characters measured are chosen according to Kauhausen (2002). He used polar coordinate system for description the location of the different intervenation points.

Because the first point is chosen randomly, it has no values on the coordinate system $(\mathrm{X}=0$ and $\mathrm{Y}=0)$. The second point, however, was represented by one value on the first reference point. All the remaining points are represented by two values. The number of points chosen were 17 (Fig. 1), so the number of the coordinates be (2 $\mathrm{X} 17)-3=31$ points, which represent the measured characters (Table, 1).

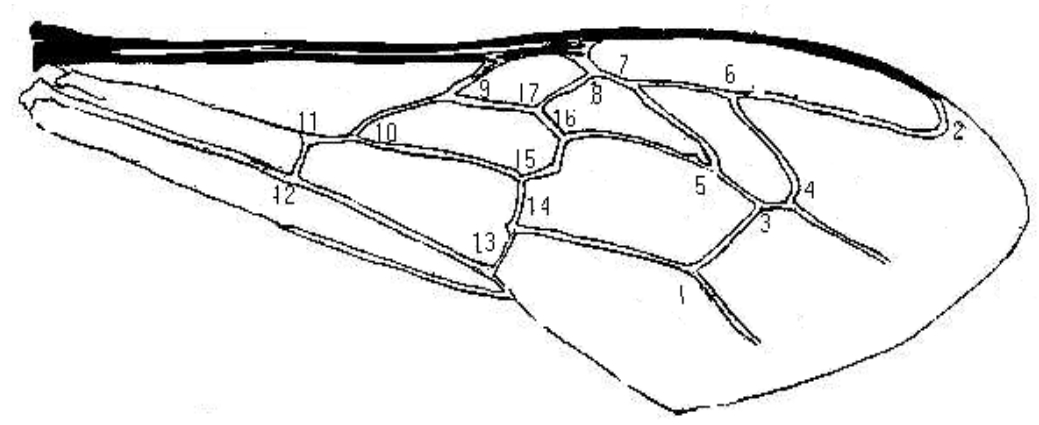

Fig. 1: Forewing of worker bees showing 17 points used to establish wing coordinates 
Table1: Characters measured on the forewing

\begin{tabular}{|c|c|c|}
\hline No & $\begin{array}{l}\text { Distance (L) and Angles (A) between } \\
\text { coordinates }\end{array}$ & $\begin{array}{l}\text { Morphometrical characters in relation to the first } \\
\text { coordinates }(1,2) \text { (Fig 1) }\end{array}$ \\
\hline 1 & L1 & $1-2$ \\
\hline 2 & L2 & $1-3$ \\
\hline 3 & A2 & $2-1-3$ \\
\hline 4 & L3 & $1-4$ \\
\hline 5 & A3 & $2-1-4$ \\
\hline 6 & L4 & $1-5$ \\
\hline 7 & A4 & $2-1-5$ \\
\hline 8 & L5 & $1-6$ \\
\hline 9 & A5 & $2-1-6$ \\
\hline 10 & L6 & $1-7$ \\
\hline 11 & A6 & $2-1-7$ \\
\hline 12 & L7 & $1-8$ \\
\hline 13 & A7 & $2-1-8$ \\
\hline 14 & L8 & $1-9$ \\
\hline 15 & $\mathrm{~A} 8$ & $2-1-9$ \\
\hline 16 & L9 & $1-10$ \\
\hline 17 & A9 & $2-1-10$ \\
\hline 18 & L10 & $1-11$ \\
\hline 19 & A10 & $2-1-11$ \\
\hline 20 & L11 & $1-12$ \\
\hline 21 & A11 & $2-1-12$ \\
\hline 22 & L12 & $1-13$ \\
\hline 23 & A12 & $2-1-13$ \\
\hline 24 & L13 & $1-14$ \\
\hline 25 & A13 & $2-1-14$ \\
\hline 26 & L14 & $1-15$ \\
\hline 27 & A14 & $2-1-15$ \\
\hline 28 & L15 & $1-16$ \\
\hline 29 & A15 & $2-1-16$ \\
\hline 30 & L16 & $1-17$ \\
\hline 31 & A16 & $2-1-17$ \\
\hline
\end{tabular}

\section{Equipment and measurement procedure}

The morphometrical system used consisted of the following parts:

1. Computer unit with a suitable analyzing program developed by Kauhausen (2002).

2. A Slide-Scanner (Minolta Dimâge Scan Dual 11).

The wing measurements were made by using a $35 \mathrm{~mm}$ slide projector to project the images of mounted wings onto a monitor screen. A particular type of slide known as a Gepe consists of two plastic half frames containing thin metal masks and each half frame is separately glazed. From each worker bee, the left and right fore wings was cut off at the base with a fine forceps and dry-mounted onto slides. Each slide had 15 fore wings, and each 4 slides were put in a slide mount holder, which was then put inside the Scanner, in order to scan the mounted wings. After setting a suitable display-program, the wings were displayed on the screen monitor of a computer, and by the computer-mouse, the different intervenation points were marked.. The measuring-program converted these coordinate points into actual lengths and angles of the different intervenation points relative to the first two points. The converted measurements are then stored in a new file.

For every bee sample, the converted data, the information about its origin, the type of bees, to which it belongs, and the date of collection were registered in a data-bank.

The bees were prepared and measured in bee section of Faculty of Agriculture, Cairo University. 


\section{Anomalies of wing venation:}

The right fore and hind wing of each worker bee was examined using a stereomicroscope. At least ten forewings were sampled from each colony and examined for the presence of any unusual veins. In the forewing, the unusual veins were searched on in 5 wing cells (Fig.2), and in all hind wing cells. These unusual extra veins were scored as present only if a measurable vein length could be detected, while slight thickenings were ignored.

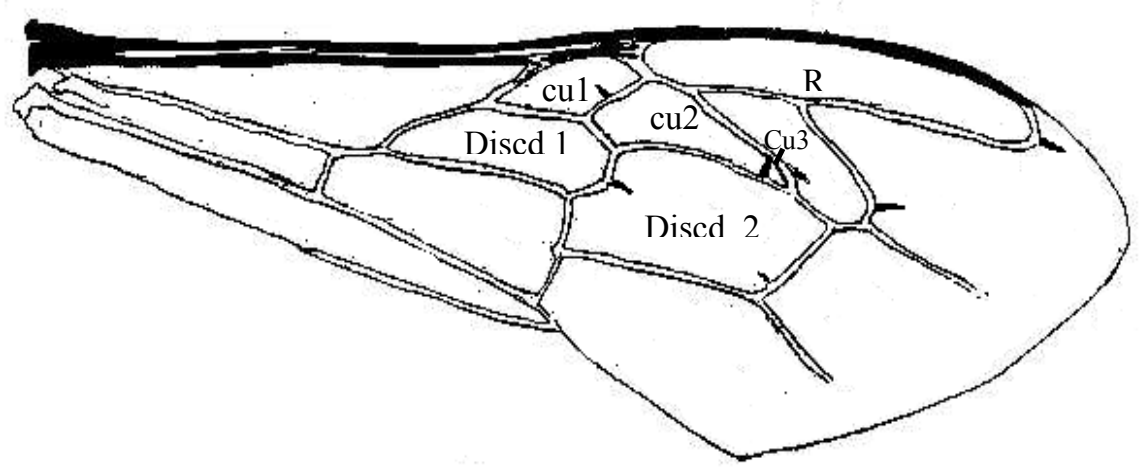

Fig. 2: Forewing venation pattern showing the different wing cells with different kinds of extra-veins shown as small black.veins.

$\mathbf{R}=$ Radial cell, $\mathbf{C u 1}=$ first cubital cell, $\mathbf{C u 2}=$ second cubital cell $\mathbf{C u} \mathbf{C}=$ third cubital cell, Discd1 $=$ first discoidal cell, Discd2 $=$ second discoidal cell

\section{Statistical analysis:}

In the present study, a subsample of 32 worker bees, randomly collected from each group and 2 replicate measurements were made for different traits per bee for calculating measurement error. The second set of measurements was made on different days and without the reference to the first set.

A mixed model 2-way ANOVA was used to assess asymmetry in each trait (Palmer and Strobeck C. 1986). In this model, "individual" is a random factor that assesses variation among individuals, whereas "sides" is a fixed factor that assesses directional asymmetry (DA). The "individual_sides interaction" assesses fluctuating asymmetry (FA), and the "error" assesses variation in the replicate measurements.

Discriminant analysis was carried out and Bartlett's $X^{2}$ statistics was used to show the significance of the discriminant function (Jobson, 1992). In addition, Euclidean distance between the left and right wing was estimated to show the degree of homogeneity between the two wings for each group (Holm, 2010).

In addition, chi square analysis was conducted to show the significance between different percentage of wing anomalies.

\section{RESULTS}

\section{Asymmetry of wing venation:}

As the results indicate in Table (2), and concerning the two way analysis of variance, both the difference between left and right wing, which indicate directional asymmetry, and the interaction between sides and individuals, which indicate fluctuating asymmetry, showed significant differences in different numbers of characters in the three groups. 
Table 2: Asymmetry analysis of the different wing coordination (FA: Fluctuating asymmetry \& DA: Directional asymmetry.)

\begin{tabular}{|c|c|c|c|c|c|c|c|}
\hline \multirow[t]{2}{*}{ No } & \multirow{2}{*}{$\begin{array}{l}\text { Distance }(\mathrm{L}) \\
\text { and Angles } \\
\text { (A) between } \\
\text { coordinates }\end{array}$} & \multicolumn{2}{|c|}{ A.m. lamarckii } & \multicolumn{2}{|c|}{$\begin{array}{c}\text { A. m. carnica } \\
\text { (Manzala) }\end{array}$} & \multicolumn{2}{|c|}{$\begin{array}{l}\text { A.m. carnica } \\
\text { (New Valley) }\end{array}$} \\
\hline & & $F A$ & $D A$ & $F A$ & $D A$ & $F A$ & $D A$ \\
\hline 1 & L1 & $6.3 * *$ & $0.65(\mathrm{~ns})$ & $9.14 * *$ & $1.31(\mathrm{~ns})$ & $20.29 * *$ & $244.34 * *$ \\
\hline 2 & $\mathrm{~L} 2$ & $14 * *$ & $51.94 * *$ & $15.85 * *$ & $43.17 * *$ & $15.58 * *$ & $27.45 * *$ \\
\hline 3 & A2 & $11.45 * *$ & $28.2 * *$ & $7.32 * *$ & $9.69 * *$ & $24.17 * *$ & $60.78 * *$ \\
\hline 4 & L3 & $11.27 * *$ & $43.15 * *$ & $4.58 * *$ & $1.12(\mathrm{~ns})$ & $8.61 * *$ & $45.18 * *$ \\
\hline 5 & A3 & $17.46 * *$ & $32.45 * *$ & $8.27 * *$ & $24.75^{* *}$ & $11.85 * *$ & $7.28 * *$ \\
\hline 6 & $\mathrm{~L} 4$ & $1.22(\mathrm{~ns})$ & $1.98(\mathrm{~ns})$ & $14.96 * *$ & $5.63 * *$ & $7.04 * *$ & $149 * *$ \\
\hline 7 & A4 & $1.31(\mathrm{~ns})$ & $2.76(\mathrm{~ns})$ & $14.03 * *$ & $111.6 * *$ & $38.49 * *$ & $173.18 * *$ \\
\hline 8 & L5 & $1.46(\mathrm{~ns})$ & $1.13(\mathrm{~ns})$ & $9.84 * *$ & $2.73(\mathrm{~ns})$ & $9.51 * *$ & $11.19 * *$ \\
\hline 9 & A5 & $7.73 * *$ & $19.61 * *$ & $39.52 * *$ & $34.67 * *$ & $37.94 * *$ & $203.09 * *$ \\
\hline 10 & L6 & $1.28(\mathrm{~ns})$ & $4.6^{*}$ & $35.41 * *$ & 00(ns) & $6.98 * *$ & $127.4 * *$ \\
\hline 11 & A6 & $1.6(\mathrm{~ns})$ & $0.18(\mathrm{~ns})$ & $18.46 * *$ & $0.03(\mathrm{~ns})$ & $14.89 * *$ & $1.91(\mathrm{~ns})$ \\
\hline 12 & L7 & $1.71 *$ & $12.41 * *$ & $16 * *$ & $0.06(\mathrm{~ns})$ & $10.41 * *$ & $179.8 * * 2$ \\
\hline 13 & A7 & $2.57 * *$ & $0.48(\mathrm{~ns})$ & $15.24 * *$ & $0.54(\mathrm{~ns})$ & $11.16 * *$ & $28.6 * *$ \\
\hline 14 & L8 & $1.2(\mathrm{~ns})$ & $0.29(\mathrm{~ns})$ & $20.44 * *$ & $13.4 * *$ & $18.16^{* *}$ & $139.6 * *$ \\
\hline 15 & A8 & $1.24(\mathrm{~ns})$ & $0.82(\mathrm{~ns})$ & $14.35 * *$ & $17.27 * *$ & $11.69 * *$ & $182.16^{* *}$ \\
\hline 16 & L9 & $1.26(\mathrm{~ns})$ & $0.003(\mathrm{~ns})$ & $25.16 * *$ & $0.82(\mathrm{~ns})$ & $21.4 * *$ & $0.36(\mathrm{~ns})$ \\
\hline 17 & A9 & $1.61(\mathrm{~ns})$ & $3.41(\mathrm{~ns})$ & $27.34 * *$ & $22.43 * *$ & $17.33 * *$ & $294.37 * *$ \\
\hline 18 & L10 & $1.22(\mathrm{~ns})$ & $0.56(\mathrm{~ns})$ & $12.95 * *$ & $2.12(\mathrm{~ns})$ & $8.07 * *$ & $17.67 * *$ \\
\hline 19 & A10 & $7.64 * *$ & $47.01 * *$ & $26.56 * *$ & $25.56 * *$ & $14.34 * *$ & $215.45 * *$ \\
\hline 20 & L11 & $3.46^{* *}$ & $1.47(\mathrm{~ns})$ & $42.16^{* *}$ & $0.15(\mathrm{~ns})$ & $39.02 * *$ & $1.66(\mathrm{~ns})$ \\
\hline 21 & A11 & $4.93 * *$ & $29.58 * *$ & $26.95 * *$ & $24.31 * *$ & $17.83 * *$ & $293.2 * * 2$ \\
\hline 22 & L12 & $0.97(\mathrm{~ns})$ & $0.3(\mathrm{~ns})$ & $11.7 * *$ & $0.83(\mathrm{~ns})$ & $17.76 * *$ & $10.36 * *$ \\
\hline 23 & A12 & $1.27(\mathrm{~ns})$ & $3.72(\mathrm{~ns})$ & $16.85 * *$ & $12.4 * *$ & $8.84 * *$ & $291.53 * *$ \\
\hline 24 & L13 & 0.99 (ns) & $0.02(\mathrm{~ns})$ & $18.77 * *$ & $10.85 * *$ & $11.02 * *$ & $0.07(\mathrm{~ns})$ \\
\hline 25 & A13 & $1.45(\mathrm{~ns})$ & $6.27^{*}$ & $17.69 * *$ & $30.62 * *$ & $8.29 * *$ & $138 . * * 1$ \\
\hline 26 & L14 & $4.39 * *$ & $24.99 * *$ & $28.19 * *$ & $29.8^{* *}$ & $7.67 * *$ & $11.05 * *$ \\
\hline 27 & A14 & $1.17(\mathrm{~ns})$ & $3.28(\mathrm{~ns})$ & $21.41 * *$ & $23.03 * *$ & $13.19 * *$ & $83.81 * *$ \\
\hline 28 & L15 & $1.7 *$ & $3.98(\mathrm{~ns})$ & $61.05 * *$ & $42.23 * *$ & $47.66 * *$ & $243.45 * *$ \\
\hline 29 & A15 & $1.12(\mathrm{~ns})$ & $1.92(\mathrm{~ns})$ & $11.92 * *$ & $4.72 *$ & $16.34 * *$ & $150.2 * *$ \\
\hline 30 & L16 & $7.39 * *$ & $65.96 * *$ & $82.14 * *$ & $0.01(\mathrm{~ns})$ & $37.58 * *$ & $245.06^{* *}$ \\
\hline 31 & A16 & $8.46 * *$ & $29.7 * *$ & $22.53 * *$ & $8.9 * *$ & $13.21 * *$ & $120.24 * *$ \\
\hline
\end{tabular}

* significace at $\mathrm{P}<0.05$

$* *$ significace at $\mathrm{P}<0.01$ 
Concerning Carniolan bee in both Manzala and New Valley, all characters showed significant (FA), but 19 and 27 of 31 characters showed significant directional asymmetry in the two groups, respectively.

In Egyptian bees, 15 characters of 31 showed significant fluctuating asymmetry, and 13 showed directional asymmetry.

In addition to the previous univariate analysis of each character, discriminant analysis was carried out to compare the multivariate means of left and right wings. For this purpose, Bartlett's $X^{2}$ statistics was used to show the significance of the discriminant function. As the results indicated, the first factor extracted could discriminate left and right wing significantly from each other in Carniolan bee from Manzala and New Valley $\left(\mathrm{ch}^{2}=161.89,152.18 ; \mathrm{P}<0.01\right)$, while the difference was not significant in Egyptian bees $\left(\mathrm{ch}^{2}=16.02 ; \mathrm{P}>0.05\right)$.

Euclidian distance was calculated to give overall view on the similarity between the two wings in each group (Fig. 5). The Euclidean distance between left and right wing in Egyptian bees was found to be smaller (0.67) than the distance in Manzala and New Valley (1.49 and 1.52, respectively).

\section{Anomalies of wing venation:}

The deformations of fore- and hindwing venation pattern were expressed in terms of extra and incomplete veins. As shown in Table (3), and with respect to wing venation pattern of the forewing, the highest rate of abnormal veins was registered in marginal cells. Marginal cell is an elongated cell with rounded apex set off from wing margin. The apical region of this cell shows an extra vien which appear with different lengthes in front of the marginal cells. The highest ratio of worker bees having this extra vein was registered in Egyptian bees at a rate of $12.5 \%$, while it was $7.6 \%$ and $5.6 \%$ in Carniolan bees from Manzala and New Valley, respectively.

In Egyptian bees, the adventitious veins in cub 1 are absent, while it occur at a very low proportion in Carniolan bees from Manzala. In New Valley population, however, it occur at a proportion of $2.2 \%$.

Concerning Cub2, the adventitious vein occur at a proportion of 3\% in both Egyptian and Carniolan bees from Manzala district, while it was $1.6 \%$ in bees from New Valley district.

The adventitious veins in Cub 3 are present at relatively very high proportion $(9 \%)$ in the southern population of Carniolan bees (New Valley), while it occur at moderate frequency in northern Carniolan population in Manzala (6.4\%) and at very low frequency in Egyptian bees $(0.8 \%)$.

Concerning second discoidal cell, the rate of worker having extra vein ranged from 1.8 and $1.2 \%$, in Egyptian, and Carniolan bees from Manzala, while no extra veins were observed in New Valley in this wing cell.

No incomplete vein was noticed in the all the wing cells under study except the third cubital cell. It appear in Carniolan population with low frequency $(0.2$ $0.4 \%$ ). In this cell the $1 \mathrm{r}-\mathrm{sm}$ missed its apical sector and $2 \mathrm{rs}-\mathrm{m}$ missed its basal sector (Fig. 3).

New Valley Carniolan bees had a higher frequency of wing venation abnormalities than Egyptian bees $(\mathrm{chi}=5.11$, df $=1, \mathrm{P}<0.05)$, or than Manzala Carniolan bees $(\mathrm{chi}=0.52, \mathrm{df}=1, \mathrm{P}>0.05)$.

Concerning hind wing, only the extension of medial vein was observed among the three populations (Fig. 4). In Egyptian bees, the rate of bees having this extension was $64 \%$ while it was $2 \%$ and $6 \%$ in Manzala and New Valley, resp. (Table, 3 ). 
Table 3: Number of wing venation anomalies in fore- and Hindwing at different wing cells of Egyptian, Carniolan (Manzala and New Valley) worker bees

\begin{tabular}{|c|c|c|c|c|c|}
\hline Wing cells & Anomalies & $\begin{array}{l}\text { Egyptian bees } \\
\qquad(\mathrm{n}=550)\end{array}$ & $\begin{array}{c}\text { Carniolan bees } \\
\text { (Manzala) } \\
(n=500)\end{array}$ & $\begin{array}{c}\text { Carniolan bees } \\
\text { (NewValley) } \\
(\mathrm{N}=515)\end{array}$ & Total \\
\hline \multirow{2}{*}{ Forewing } & Extra veins & 0 & 1 & 11 & \\
\hline & Incomplete vein & 0 & 0 & 0 & \\
\hline \multirow[t]{2}{*}{ Cubital cell 1} & Total & $\mathbf{0}$ & $1(0.2 \%)$ & $11(2.1 \%)$ & $12 a$ \\
\hline & Extra veins & 8 & 8 & 15 & \\
\hline \multirow{3}{*}{ Cubital cell 2} & Incomplete vein & 0 & 0 & 0 & \\
\hline & Total & $8(1.4 \%)$ & $8(1.6 \%)$ & $15(2.9 \%)$ & 31b \\
\hline & Extra veins & 4 & 32 & 45 & \\
\hline \multirow[t]{3}{*}{ Cubital cell 3} & Incomplete vein & 0 & 1 & 2 & \\
\hline & Total & $4(0.7 \%)$ & $33(6.6 \%)$ & $47(9.1 \%)$ & $84 c$ \\
\hline & Extra veins & 63 & 38 & 28 & \\
\hline \multirow[t]{3}{*}{ Marginal cell } & Incomplete vein & 0 & 0 & 0 & \\
\hline & Total & 63 & $38(7.6 \%)$ & $28(5.4 \%)$ & 129d \\
\hline & Extra veins & 9 & 6 & 0 & \\
\hline \multirow{2}{*}{$\begin{array}{l}\text { Discoidal } \\
\text { cell } 2\end{array}$} & Incomplete vein & 0 & 0 & 0 & \\
\hline & Total & 9 & 6 & $\mathbf{0}$ & $15 \mathbf{a}$ \\
\hline Total & & $84 a$ & 86ab & 111b & \\
\hline \multirow{3}{*}{$\begin{array}{c}\text { Hind wing }(\mathrm{n}=200) \\
\text { Distal abscissa } \\
\text { of } \mathrm{M} \text { vein }\end{array}$} & Extra veins & 128 & 4 & 12 & \\
\hline & Incomplete vein & $\mathbf{0}$ & $\mathbf{0}$ & $\mathbf{0}$ & \\
\hline & Total & $128(64 \%)$ & $4(2 \%)$ & $12(6 \%)$ & \\
\hline
\end{tabular}

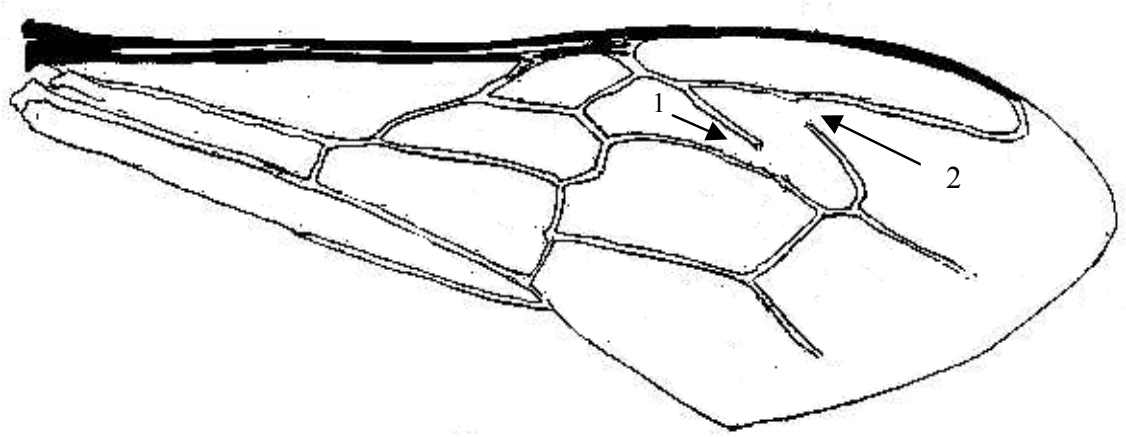

Fig. 3: Forewing venation pattern showing the different wing cells with two incomplete-veins (1 and 2) in $1 \mathrm{r}$-sm and $2 \mathrm{r}$-sm veins. 


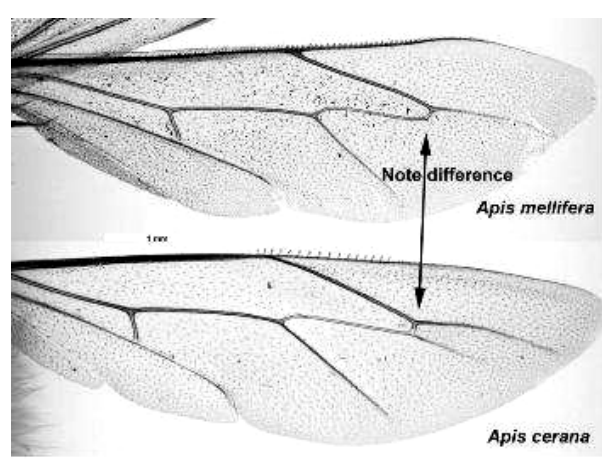

Fig (4): Extra medial vein of the hind wing in $A$. Cerana and A. mellifera

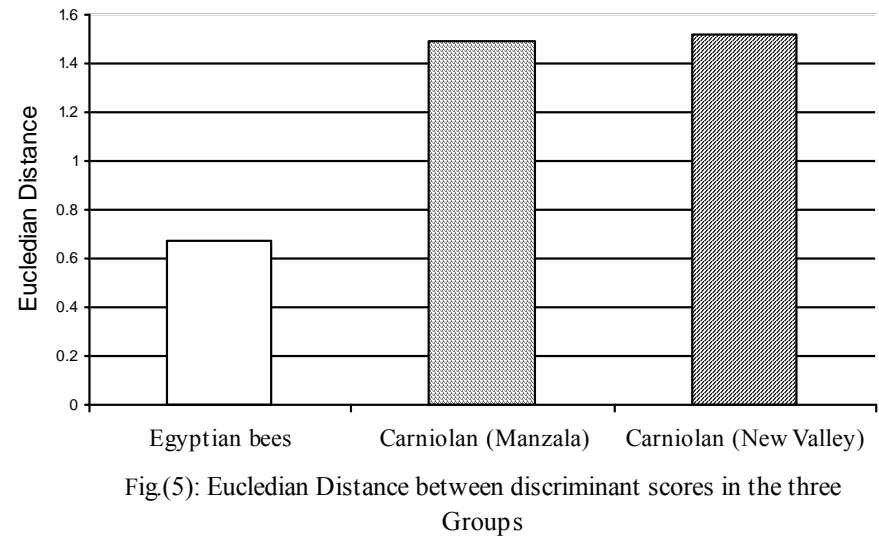

Groups

\section{DISCUSSION}

Comparing the appearing of different extra or incomplete veins between different wing cells, it could be remarked that the most extra veins in the fore and hind wing appear in the marginal wing cell. Both marginal and third cubital cell in the forewing and radial cell in the hind wing have the most frequent number of adventitious veins. As well, most of those veins are external, that is, it extend outside of the cell and fewer appear internally. The veins of those cells may be more sensitive to the selective pressures factors than other wing cells. These could be declared by knowing that along the evolution of wing venation pattern, one can expect that the most pressure applies on the wing cell located at the apical region of the wing, which may stretch the wing by adding extra veins. The sensitive of apical wing cells to the selective pressure factors could also be emphasized by using them for the discrimination of honeybee populations (Goetze, 1964; Klebs, 1995; Francoy et al, 2007).

Comparing anomalies and asymmetry of wing venation pattern between Egyptian and Carniolan bees, it could be concluded that Egyptian bees have lower rates of wing venation anomalies and lower number of characters showing asymmetry than Carniolan bees. The result was coincided with those obtained by (Schneider et al, 2003), who stated that, African bees have lower FA for wing shape (and by inference greater developmental stability) relative to European and hybrid workers, and with. Baehrman (1963) who reported that, African bees had lower rate of veins showing extra or incomplete abscissa than European ones.

Concerning anomalies appearing in wing venation pattern, Tan (2008) reported, that the adventitious vein on the third cubital index was absent in Egyptian bees, while it occur at relatively high frequency in Carniolan bees $(10 \%)$. In the present study, the frequency of Egyptian bees having this extra vein occurred in lower frequency $(0.6 \%)$ than in Manzala and New Valley Carniolan bees (6.6 and 9.1\%, resp). European races are more recent than African race and therefore did not reach developmental stability and this may be reflected on the different extra veins. African races, on the other hand, still have a rudimentary of their recent ancestors, that is Apis cerana, and this could be seen in the high rates of Egyptian bee having an extension of the medial vein on the hind wing. 
Concerning asymmetry of wing venation pattern, the present study, and in Egyptian bees, the size difference between left and right wing concerning both directional or fluctuating was les pronounced than in Carniolan bees.

Anomalies and asymmetry of wing venation pattern could be caused by genetic or environmental factors. Smith et al., (1997), investigated the influence of hybrids between two honeybee races on the symmetry, and they found that these parameters differed between parents and their hybrids. They reported also that, the expression of genes responsible of appearing of these parameters could be differed between haploids and diploids in a species.

Schneider et al (2003), reported that African bees have lower fluctuating asymmetry for wing shape relative to European and hybrid workers. Many studies have noted a decrease in asymmetry with increasing heterozygosiety and decreasing inbreeding levels (Bruckner, 1979; Leary et. al., 1983, 1984, 1985). Hybridization between individuals from different species, subspecies or genetically differentiated populations has also been associated with an increase in fluctuating asymmetry (Smith et al., 1997).

In this study, the symmetry difference between left and right wing could be attributed to the different genetic lineages to which the two races are belong. (Sheppard and Smith 2000), or by the fact that inbreeding could negatively affect this parameter (Brueckner, 1978b \& 1979). In Egypt, the Carniolan bees have been imported from Europe for more than 60 years. In the two locations, they were kept for the native apiary and for supplying other orts in Egypt with virgin or naturally mated Carniolan bee queens. Since that time, the original populations in the two locations has increased only by producing artificial bee swarms by dividing the original colonies, and no additional colonies were imported since that time. So, the probability of appearing inbreeding effect would increases which may be reflected on the degree of the symmetry of the bees.

On the other hand, asymmetry of wing characters was found to be affected by different environmental conditions. Markow (1995) and Imasheva et al, (1997), mentioned that climatic fluctuations affect developmental stability in some invertebrates. As Savage \& Hogarth, (1999); Chapman \& Goulson, (2000); Mpho et al, (2002); Trotta et al, (2005) reported that, FA decrease at moderated temperature and tend to increase at the two extremes. So, the difference of asymmetry between Carniolan and Egyptian bees could partly attributed to the adaptation of them to different environmental factors (Winston 1992; McNally and Schneider 1992, 1996). In Egypt, both Carniolan bee populations are kept in 2 isolated areas. The different environmental factors prevails in Egypt in comparison to Europe from which Carniolan bees have been introduced. In Europe, the bees have accustomed to feed from specific plant sources which are not prevailed in Egypt. As well, the climate factors are so different that the bees could not be able to express their highest vitality. On the other hand, the Egyptian bees are native to Egypt and probably are accustomed to the different environmental factors in it.

Genetic or environmental factors could also affect the appearing of wing anomalies. The appearance of the adventitious veins in several species and sometimes with relatively high frequencies indicates that it is not a rare teratology and may represent the reacquisition of a vein long suppressed among most lineages of Hymenoptera. Baehrman (1963) stated that, because drones have higher frequency of these veins than workers or queens, these veins could be caused by recessive genes which appear mostly in haploid drones. 
The abnormality of wing venation pattern could be also caused by some environmental factors. Goetze (1959) mentioned that, extra veins appearing at the lower portion of third cubital cell may reflect a plenty of pollen sources in field or a good recombination of hybrid bees. On the other hand, the absence of this extra vein may reflect poor food condition. He mentioned, as well, that the presence of the small extra veins found on the apical portion of marginal cell indicate bees with strong body, being developed under optimal conditions.

In addition to previous explanations concerning the difference between Egyptian and Carniolan bees, and between different characters within each parameter, the two races may differ in their ability to suppress asymmetry and venation abnormalities, assuming that both parameters are measures of buffering ability and developmental stability, whether or not they have a heritable component (Smith et al., 1997). The different reactions of the characters used in detecting asymmetry and abnormality may reflect different sensitivity to developmental perturbation, and in this case, further studies are needed to detect which characters in which genotype are sensitive to a specific developmental disturbance and which are not.

Considering these parameters as race-specific characters, further studies are needed to know the nature of selective pressure which may act to maintain and have these parameters appear in higher frequency in some genotypes than others, and to know the relative importance of additive genetic and environment in causing asymmetry and abnormalities.

\section{REFERENCES}

Akahira, Y. and Sakagami, S. F. (1959). Observation on wing variability of wing venation in the honeybee. J. Faculty of science, Hokkaido University, series VI, Zool, 14: 2: 175-184.

Alpatov, W. W. (1929). Biometrical studies on variation and races of the honeybee Apis mellifera L. Q. Rev. Biol., 4 (1): 1-58

Baehrman, R. (1963). Zur Vorkommen von Anomalien im Fluegelaeder der Honigbiene. Arch. f. Bienenkunde, 40: 49-58.

Beardmore, J.A. (1960). Developmental stability in constant and flactuating temperatures. Heredity. 14: 411- 422.

Brueckner, D. (1978 a). The influence of genetic varibility on wing symmertry in honeybees (Apis mellifera). Evolution, 30: 100-108.

Brueckner, D. (1978 b). Why are there inbreeding effects in haplo-diploid system? Evolution. 32: 456 - 458.

Brueckner, D. (1979). Effects of inbreeding on worker honeybees. Bee World, 60: 137-140.

Cale, G.H. and Gowen, J. W. (1956). Heterosis in the honey bee (Apis mellifera).

Chapman, J.W., and Goulson, D. (2000).Environmental versus genetic influences on fluctuating asymmetry in the house fly, Musca domestica. Biological Journal of the Linnean Society. 70:403-413.

Clarke, G. M., and Oldroyd, B. P. (1996). The genetic basis of developmental

stability in Apis mellifera II. Relationships between character size, asymmetry and single-locus heterozygosity. Genetica 97:211-227.

Clarke, G. M.; Oldroyd, B. P., and Hunt, P. (1992). The genetic basis of developmental stability in Apis mellifera: heterozygosity versus genic balance. Evolution 46:753-762. 
Francoy, T. M; Prado, P.R.; Goncalves, L.S.; Costa, 1. D. and Jong, D.D. (2007). Morphometric differences in a single wing cell can discriminate Apis mellifera racial types. Apidologie 37, 91-97.

Goetze, G. (1936). Erbliche und nicht erbliche Merkmale im Fuegelaeder der Honigbienen. Dtscher Imkerfuherer, 10(3): 98-104.

Goetze, G. (1959). Die Bedeutung des Fluegelgeaeders fuer die zuechterische Bedeutung der Honigbiene. Zeitschrift fuer Bienenforschung,4: 141-148.

Goetze, G. (1964). Die Honigbiene in natuerlicher und kuenstlicher Zuchtauslese. Teil I und II, Paul Parey, Hamburg.

Graham, J. H. and Felley, J. D. (1985). Genomic coadaptation and developmental stability within introgressed populations of Enneacanthus gloriosus and E. obesus (Pisces, Centrarchidae). Evolution, 39: 104-1 14.

Gupta, A.P. (1978). Developmental stability in species hybrid and backcross progenies in Drosophila. Evolution, 32: 580-587.

Holm, K. (2010) - Almo-Statistik-System, Univ. Linz, Austria.

Imasheva, A.G.; Loeschcke, V.; Zhivotovsky, L.A. and Lazebny, O.E. (1997) Effects of extreme temperatures on phenotypic variation and developmental stability in Drosophila melanogaster and Drosophila buzzatii. Biological Journal of the Linnean Society, 61, 117-126.

Jobson, J.D. (1992). Applied multivariate data analysis. Vol.II, categorial and multivariate methods, New York.

Kauhausen, D.; Keller, R. (1994). Morphometrical control of pure race breeding in the honeybee (Apis mellifera). Apidologie, 25: 133-143.

Kauhausen, D. (2002). Methods of classification of honeybee races using wing characters. $2^{\text {nd }}$ European Scientific Apiculture Conference, Balatonlelle, Hungary.

Klebs, K. (1995). Rasseneinheit-Bestimmung von Carnicaherkuenften anhand morphometrischer Untersuchungen an Koeniginnenfluegeln. Schweiz. BienenZeitung, 118(12):699-703.

Klingenberg, C.P. and McIntyre, G.S. (1998). Geometric morphometrics of developmental instability: analyzing patterns of fluctuating asymmetry with Procrustes methods. Evolution. 52:1363-1375.

Leary, R. F.; Allendorf, F. W. and Knudsen, K. L. (1983). Developmental stability and enzyme heterozygosity in rainbow trout. Nature 301: 71-72.

Leary, R. F.; Allendorf, F. W. and Knudsen, K. L. (1984). Superior developmental stability of heterozygotes at enzyme loci in salmonid fishes. Amer. Nat. 124: 540-551.

Leary, R. F.; Allendorf, F. W.; Knudsen, K. L. and Thorgaard, G. H.(1985). Heterozygosity and developmental stability in gynogenetic diploid and triploid rainbow trout. Heredity 54: 219-225.

Lerner, I. M. (1954). Genetic Homeostasis. Wiley, N.Y.

Markow, T.A. (1995) Evolutionary ecology and developmental instability. Annual Review of Entomology, 40: 105-120.

Mather, K. (1953). Genetical control of stability in development. Heredity, 7: $297-$ 336.

Mattu, V. K. and Verma, L. R. (1984). Comparative morphometric studies on the indian honeybee of the North-West Himalayas. II. Wing. J. Apic. Res. (23) 3: 117-122. 
McNally, L. C. and Schneider, S. S. (1992). Seasonal cycles of growth, development and movement of the African honey bee, Apis mellifera scutellata, in Africa. Insectes Soc. 39:167-179.

McNally, L. C. and Schneider, S. S. (1996). Spatial distribution and nesting biology of colonies of the African honey bee Apis mellifera scutellata (Hymenoptera: Apidae) in Botswana, Africa. Environ. Entomol. 25:643-652.

Mpho, M.; Callaghan, A. and Holloway, G. J. (2002). Temperature and genotypic effects on the life history and fluctuating asymmetry in a field strain of Culex pipiens. Heredity, 88:307-312.

Palmer A. R and Strobeck C. (1986). Fluctuating asymmetry: measurement, analysis, patterns. Annual reviews in Ecology and Systematics. 17:391-421.

Parsons, P. A. (1992). Fluctuating asymmetry, a biological monitor of environmental and genomic stress. Heredity. 68:361-364.

Reeve, E. C. (1960). Some genetic testes on asymmetry for sternopleural chaeta number in Drosophila. Genet. Res., 7: 151-172.

Ross, K. G. and Robertson, J. L. (1990). Developmental stability, heterozygosity, and fitness in two introduced fire ants (Solenopsis invicta and S. richteri) and their hybrid. Heredity 64: 93-104.

Ruttner, F.; Tassencourt, L. and Louveaux, J. (1978). Biomertrical-statistical analysis of the geographic variability of Apis mellifera L. 1 Material and Methods, Apidologie, 9: 363-381.

Ruttner, F. (1952). Zur Dyssymmetrie des Fluegelaeders der Honigbiene. Z.f. Bienenf. 1: 11.

Ruttner, F. (1988). Biogeography and taxonomy of honeybees. Springer-Verlag, Heidlberg, Germany.

Savage, A. and Hogarth, P.J. (1999); An analysis of temperature induced fluctuating asymmetry in Asellus aquaticus. Hydrobiologia. 411:139-143.

Scneider, S.S; Leamy, L.J.; Lewis, L.A. and Hoffman, G.D. (2003). The influence of hybridization between African and European Honeybees, Apis mellifera, on asymmetry in wing size and shape. Evolution, 57(10): 2350: 2364.

Sheppard, W. S., and Smith, D. R. (2000). Identification of African derived bees in the Americas: a survey of methods. Ann. Entomol. Soc. Am. 93:159-176.

Smith, D. R.; Crespi, B.J. and Bookstein, F. L. (1997). Fluctuating asymmetry in the honey bee, Apis mellifera: effects of ploidy and hybridization. Journal of Evolutionary Biology, 10 (4): 551-574

Soose, E. (1954). Einfluss der Temperatur auf die Ausgestaltung von Fluegelindex and Pncerfarbe der Honigbiene (Apis mellifera), Arch. F. Bienenkde, 31: 49-66.

Tan, K.; Fuchs, S. and Engel, M. S. (2008). An adventitious distal abscissa in the forewing of honey bees (Hymenoptera: Apidae: Apis). Apidologie 39: 674-682.

Trotta,V.; Calboli, F.C.; Garoia, F.; Grifoni, D. and Cavicchi, S. (2005). Fluctuating asymmetry as a measure of ecological stress in Drosophila melanogaster. European journal of Entomology. 102:195-200.

Valentine, D. W. and Soule, M. E. (1973). Effect of p, pl-DDT on development stability in pectoral fin rays in the grunion, Leuresthes tenuis. Fish. Bull., 71: 357-370.

Valkama, J. and Kozlov, M. (2001). Impact of climatic factors on the developmental stability of mountain birch growing in a contaminated area. Journal of applied Ecology, 38: 665-673. 
Vishalakshi, C. and Singh, B. (2009). Fluctuating asymmetry in hybrids of sibling species, Drosophila ananassae and Drosophila pallidosa, is trait and sex specific. J. Hered., 100(2):181-191.

Wilsey, B. J.; Haukioja, E.; Koricheva, J. and Sulkinoja, M. (1998). Leaf fluctuating asymmetry increases with hybridization and elevation in tree-line birches. Ecology, 79: 2092-2099.

Winston, M.L. (1992). The biology and management of Africanized honey bees. Ann. Rev. Entomol. 37:173-193.

Woyke, J. (1987). Can the number of ovarioles of honeybee queens be estimated by external characters of living queens? Proc. Apimondia Symp. Poland, 152-155.

\section{ARABIC SUMMARY}

التعريق غير الطبيعى ودرجة التماثل الموجودة فى الجناح فى كل من النحل البلدى والكرنيولى فى مصر.

$$
\text { قسم الحشرات الاقتصادية ـ كلية الزرواعة مزيد جامعة القاهرة ـ مصر }
$$

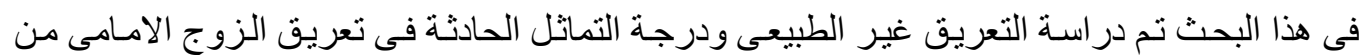

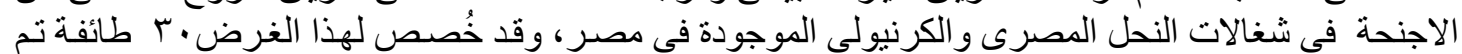

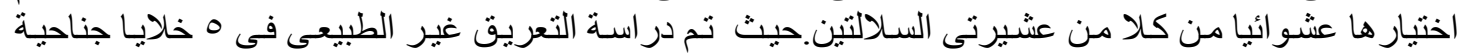

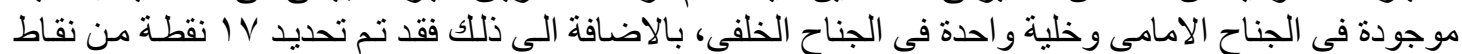

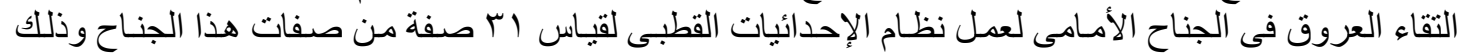

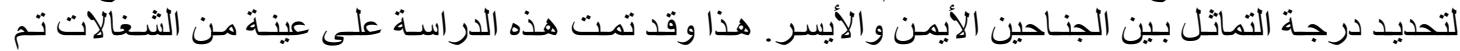

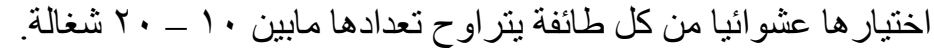

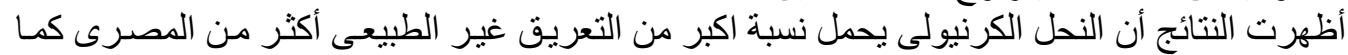

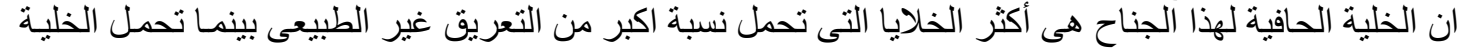

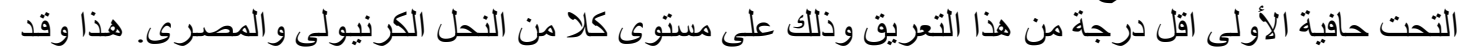

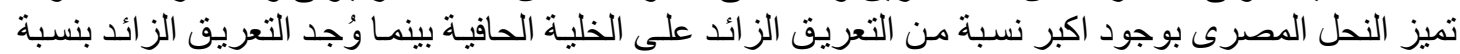
اكبر على الخلية تحت الحافية الثالثة في النحل الكرنيون التيرلى.

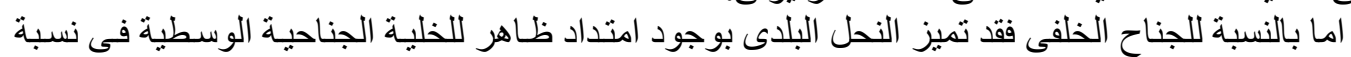

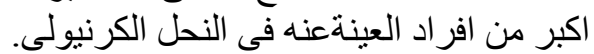

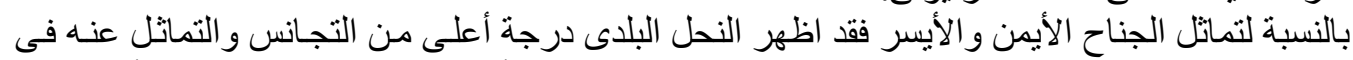

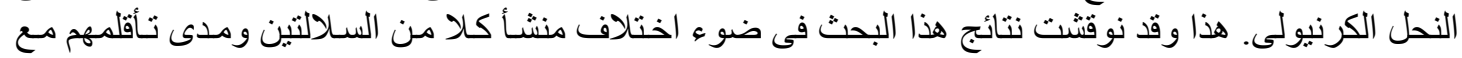
الظروف البيئية الموجودة فئ مصر نوني 